\title{
A segunda independência. Emancipadores, abolicionistas e as emancipações do Brasil
}

The Second Independence.

Emancipationists, Abolitionists and the Emancipations of Brazil

\section{José Maia Bezerra Neto}

Professor adjunto de História do Brasil da Faculdade de História e do Programa de Pós-Graduação em História Social da Amazônia na Universidade Federal do Pará (IFCH/UFPA-Belém/Brasil) e Doutor em História Social pela Pontifícia Universidade Católica de São Paulo (PUC-SP-São Paulo/Brasil). e-mail: josemaia@ufpa.br

\section{Resumo}

Este artigo trata do imaginário emancipacionista e abolicionista contra a escravidão e de sua associação com a história e memória da independência, definindo o emancipacionismo ou abolicionismo como patriótico e expressão da vontade nacional, finalizando a independência do Brasil. 0 artigo ainda demonstra a eleição de efemérides da história da emancipação escrava no Brasil, tanto por emancipacionistas como por abolicionistas, como lugares da memória associados às lutas contra a escravidão.

\section{Abstract}

This article analyses the emancipationist and abolitionist representations against slavery and its associations with the Brazilian history and memory of the Independence. This image was built as patriotic and as an expression of the national will, which, according to emancipationists and abolitionists, concluded the process of Independence. It focuses on the selection of specific events related to the emancipation of slaves.

Palavras-chave

escravidão, abolição da escravatura, identidade nacional, patriotismo, associações, Independência

Keywords

slavery, abolition of slavery, national identity, patriotism, fellowships, Independence 
Cf. Ofício do Presidente da Província, José Joaquim da Cunha, em 12 de março de 1853 ao Capitão de Fragata Inspetor do Arsenal de Marinha, Fundo: Secretaria da Presidência da Província (doravante: SPP), Série: Ofícios, Ano: 1851-1856. Caixa: 159 (Ofícios do Arsenal de Marinha do Pará), Arquivo Público do Estado do Pará, doravante APEP.

Cf. SCHWARCZ, Lilia Moritz. As barbas do imperador: D. Pedro II, um monarca nos trópicos. São Paulo: Companhia das Letras, 1998. p.292-294.

3

Cf. Ofício de José, Bispo, ao Presidente da Província, Sebastião do Rêgo Barros, em 28 de novembro de 1854, Fundo: SPP, Série: Ofícios, Ano: 1853-1854. Caixa: 175 (Ofícios das Autoridades Eclesiásticas), bem como, Ofício de 24 de novembro de 1858, Fundo: SPP, Série: Livro de Registros de Ofícios dirigidos pela Presidência da Província à Guarda Nacional, Ano: 1858-1860 n.1308; e Ofício 468, Fundo: SPP, Série: Livro de Registro dos Ofícios dirigidos pela Presidência da Província ao Comando das Armas, Ano: 18581859, n. 1296. APEP.

4

Cf. Ofício número 286 do Inspetor da Pagadoria Militar do Pará ao Presidente da Província, Fausto Augusto de Aguiar, em 18 de dezembro de 1851, Fundo: SPP, Série: Ofícios, Ano: 1851. Caixa: 153 (Ofícios da Pagadoria Militar do Pará). APEP.

5

Cf. SALLES, Vicente. Memorial da Cabanagem: esboço do pensamento político-revolucionário no Grão-Pará. Belém: Cejup, 1992. p.160.
Algumas festas cívicas, para começo de história

Em 12 de março de 1853, o presidente provincial do Pará, José Joaquim da Cunha, oficiara ao Inspetor do Arsenal de Marinha que sendo "o dia 14 de março corrente o de Anniversario Natalicio de Sua Magestade A Imperatriz [Teresa Cristina] e devendo solemnizar-se esse dia com todas as demonstrações de publico regosijo", devia ele "assistir com os Empregados de sua Repartição ao Cortejo á Effigie de Sua Magestade 0 Imperador que terá logar no Palácio da Presidência as 11 horas da manhã do referido dia". Como era um ofício circular, embora dirigido ao Inspetor, outros de igual teor foram destinados a outras autoridades. Não só pelo assunto tratado, mas por sua própria forma, documento impresso com espaços em branco para preenchimento, ${ }^{1}$ tais ofícios padronizados eram usados em outras ocasiões, como, por exemplo, nas festas cívicas do aniversário natalício do imperador Pedro II, a 2 de dezembro.

As celebrações do 2 de dezembro, que comemoravam o aniversário do Imperador, eram mais comuns que aquela realizada em 14 de março de 1853 em favor da imperatriz Teresa Cristina, esta uma cerimônia mais modesta. Até porque, mesmo fazendo parte do calendário cívico, o 14 de março não era data festiva oficial, tal qual o 2 de dezembro. Aliás, nas festas consagradas à imperatriz, tal como a que citei, a imagem pública reverenciada era a do imperador. Enfim, o 2 de dezembro festejado com pompa e gala que a circunstância pedia era no $2^{\circ}$ Reinado objeto das preocupações das autoridades. ${ }^{2}$ Em 28 de novembro de 1854, por exemplo, José Afonso de Morais Torres, Bispo do Pará, no mesmo dia em que recebeu ofício do presidente provincial, Sebastião do Rêgo Barros, Ihe deu ciência dos preparativos "para o acto religioso pelo anniversario natalício de S. M. 0 Imperador" na "cathedral as 10 horas da manhã do dia 2 de dezembro vindouro". 3 Já em 24 de novembro de 1858, Ambrosio Leitão da Cunha, presidente provincial, ordenou ao Barão de Jaguarary, Comandante Superior da Guarda Nacional de Belém, que os efetivos da Guarda ficassem à disposição do Comando de Armas da Província, informando a este suas ordens para os membros da Guarda Nacional "concorrerem com os de $1^{\text {a }}$ Linha á parada geral que deve haver no dia 2 de Dezembro próximo futuro Anniversario Natalicio de Sua Magestade 0 Imperador".

0 testemunho da força do apelo imagético do 2 de dezembro junto à sociedade oitocentista se percebe a partir de outros exemplos. Em 18 de dezembro de 1851, o Inspetor da Pagadoria Militar do Pará respondera ao presidente provincial, Fausto Augusto de Aguiar, que nem a Instrução de 10 de janeiro de 1843 ou outra qualquer lei até então "autorizava a despeza com luzes para illuminação em dias de festividade Nacional", testemunhando "serem estas despezas feitas pelo Officiaes ou Guarnição dos Quartéis illuminados", não considerando "autorizavel a despeza do pedido feito pelo Tenente Coronel Graduado Commandante das Companhias Provisórias de Caçadores de $1^{1}$ Linha desta Província" relativa ao azeite e fio de algodão usado "para illuminação do Quartel" na noite do dia 2 de dezembro, embora a decisão fosse da presidência da província. ${ }^{4}$ Independente, portanto, de recursos públicos, parecia haver uma prática de oficiais e guarnição custearem as despesas com tais luzes. Apelo imagético esse que também explica o nome dado à Sociedade Beneficente 2 de Dezembro, fundada em 12 de janeiro de 1871 por segmentos da classe trabalhadora em Belém, uma homenagem ao imperador e ao regime imperial desvinculada do aparelho burocrático estatal. ${ }^{5}$ 
6

Cf. SCHWARCZ, Lilia Moritz. Op. Cit., p.255.

7

Sobre a importância dessas datas no calendário cívico brasileiro, ainda no período regencial, conferir o testemunho de Kidder. Apud. SCHWARCZ, Lilia Moritz. Op. Cit., p.254-255.

Sobre o assunto ver, entre outros, mas principalmente: DIAS, Maria Odila Leite da Silva. A interiorização da metrópole e outros estudos. São Paulo: Alameda, 2005; e MATTOS, IImar Rohloff de. 0 tempo Saquarema. A formação do estado imperial. São Paulo: Hucitec, 1990.

9

Cf. HOLANDA, Sérgio Buarque de. A herança colonial - sua desagregação. In: ___ (org). História Geral da Civilização Brasileira. Tomo II: o Brasil monárquico. Vol.01: 0 processo de emancipação. São Paulo: DIFEL, 1962. p.9-39.

Cf. Ofícios 349, ano de 1858, e 385, em 1859. Fundo: SPP, Série: Livro de Registro dos Ofícios dirigidos pela Presidência da Província ao Comando das Armas, Ano: 1858-1859, n.1296; Ofícios de $1^{\circ}$ de setembro 1858,31 de agosto de 1859, 5 de setembro de 1859, 6 de setembro de 1859 e Ofício de 9 de setembro de 1859. Fundo: SPP, Série: Livro de Registros de Ofícios dirigidos pela Presidência da Província à Guarda Nacional, Ano: $1858-1860$, n. 1308.
Lilia Schwarcz já tratara da importância desse calendário cívico em torno da figura do monarca e da família imperial brasileira. Diz a autora que "a cada 2 de dezembro a memória do imperador - marcada com a lembrança de seu aniversário - se multiplicava pelo país afora".6 Era então o 2 de dezembro uma das datas cívicas comemorada no império, ao lado de outras como, por exemplo, o 25 de março, dia do juramento da constituição de 1824; 07 de abril, aniversário da ascensão do imperador ao trono; ou 07 de setembro, dia da proclamação da independência. ${ }^{7}$

07 de setembro era a efeméride de maior envergadura. Ainda mais no caso de uma jovem nação que só na década de 1850 consolidara sua emancipação política preservando a unidade nacional sob o governo da Corte. ${ }^{8}$ Daí porque, em meados do século XIX, parecia não haver empenho oficial do governo imperial em festejar as independências das províncias incorporadas à Corte, mas tão-somente a data nacional do 7 de setembro. Provavelmente, nas décadas de 1850 e seguintes, esta situação decorria dos traumas políticos ainda recentes do período regencial com suas rebeliões e guerras civis, algumas delas associadas ao sentimento de separatismo. Era, portanto, reação aos sentimentos de autonomia regional herdados do período colonial, como já dissera Sérgio Buarque de Holanda, e que ameaçavam a centralidade do poder imperial. ${ }^{9}$ Assim, penso ser este o motivo pelo qual não encontrei em documentos do governo provincial da época referências sobre comemorações do 15 de agosto, data da "adesão" paraense, sendo seus festejos iniciativas de segmentos da sociedade civil.

No Pará, na década de 1850, os festejos cívicos do 15 de agosto eram comemorações feitas por segmentos da sociedade civil, embora sempre associados à ideia de unidade nacional. Foi assim que a Sociedade Ypiranga, cujo nome remetia ao lugar de nascimento do Brasil-Nação, organizada para comemorar o 7 de setembro, também tratou de festejar o 15 de agosto, conforme comento depois. Enfim, embora fosse dado algum apoio governamental para celebração da "adesão" paraense, os presidentes provinciais não tratavam em sua correspondência oficial com outras autoridades de assuntos relativos ao 15 de agosto, como faziam em relação ao 7 de setembro. Os presidentes Ambrosio Leitão da Cunha, em 1858, e Frias de Vasconcellos, em 1859, por exemplo, enviaram ofícios ao Comando das Armas da Província tratando da "parada geral" em homenagem ao dia da independência brasileira, mas nada trataram acerca do 15 de agosto, segundo o Livro de Registro dos Ofícios dirigidos pela Presidência da Província ao Comando das Armas, para os anos de 1858 e 1859. Também pela leitura do Livro de Registro de Ofícios dirigidos pela Presidência da Província à Guarda Nacional, relativo aos anos de 1858 a 1860, a presidência da província não tratou do 15 de agosto, mas oficiou sobre 07 de setembro ordenando a participação da Guarda Nacional em suas celebrações, bem como no 2 de dezembro e na festa em homenagem a N. S. de Nazaré. Quando da parada militar do 7 de setembro de 1859, o presidente Manoel Frias de Vasconcellos, impressionado com o desfile da Guarda Nacional da capital, elogiou, em ofício ao seu comandante Barão de Jaguarary, o "aceio, o garbo e disciplina com que se apresentarão os Batalhões da Guarda Nacional", cumprindo assim com os seus "deveres como cidadãos".10

A relevância do 7 de setembro se observa também na escolha desta efeméride para solenização de importantes ações políticas imperiais, como ocorreu com a abertura do Amazonas à navegação estrangeira em 7 de 
Sobre o antilusitanismo para outros tempos e lugares no Brasil ver, por exemplo, RIBEIRO, Gladys Sabina. A liberdade em construção: identidade nacional e conflitos antilusitanos no Primeiro Reinado. Rio de Janeiro: Relume-Dumará, 2002; e Mata Galegos: Os Portugueses e os conflitos de trabalho na Republica Velha. São Paulo: Brasiliense, 1990, v.129.

12

Cf. Portarias do Subdelegado de Polícia da Vila de Vizeu, Isidoro José da Silva, aos Inspetores de Quarteirão em 15 e 19 de outubro de 1874 Fundo: Secretaria de Polícia da Província, Série: Portarias, Ano: 1874, 1885. APEP.

13

Cf. SALLES, Vicente. Memorial da Cabanagem... Op. Cit., p.162-170; e Idem. Marxismo, socialismo e os militantes excluídos. Capítulos da História do Pará. Belém: Editora Paka-Tatu, 2001. p.113-116. Ver, ainda, para informações do jornal $A$ Tribuna, Biblioteca Pública do Pará. Jornais Paraoaras: catálogo. Belém, Secretaria de Estado de Cultura, Desportos e Turismo, 1985. p.57.

14

Cf. Espancamento. Diário de Notícias, 3 de julho de 1884, p.2.

15

Sobre o 2 de julho e suas comemorações na Bahia, ver: ALBUQUERQUE, Wlamyra Ribeiro de. Algazarra nas ruas. Comemorações da independência na Bahia (1889-1923). Campinas: Unicamp/Cecult, 1999. No caso do 15 de agosto e suas festas no Pará somente conheço para o período republicano o trabalho de MORAES, Cleodir da Conceição. O Pará em Festa: política e cultura nas comemorações do sesquicentenário da Adesão (1973). 2006. 228f. Dissertação (Mestrado em História Social da Amazônia), Instituto de Filosofia e Ciências Humanas, Universidade Federal do Pará, Belém, 2006.

16

Sobre a Sociedade Beneficente 28 de Julho, ver BEZERRA NETO, José Maia. Por todos os meios legitimos e legais: as lutas contra a escravidão e os limites da abolição (Brasil, Grão-Pará: 1850-1888). 2009. 468f. Tese (Doutorado em História Social). Programa de Estudos Pós-Graduados, PUC-SP, São Paulo, 2009. Na década de 1880 , outra associação de maranhenses em Belém foi fundada, sendo em 2 de outubro de 1882 solicitada a aprovação de seus estatutos ao governo provincial, no caso a Sociedade Beneficente Protetora "União Maranhense", não sendo possivel saber se era somente uma associação mutualista. Cf. Ofício da Sociedade Beneficente Protetora "União Maranhense" ao Presidente da Província do Pará, em 2 de outubro de 1882, Fundo: SPP, Série: Ofícios, Ano:1880-1882. Caixa: 382 (Ofícios das sociedades e associações), APEP. setembro de 1867. Também, como parte e para além do clima festivo oficial e popular da data, às vezes sua comemoração tornava-se oportunidade para acirramento dos ânimos patrióticos contra os portugueses residentes no Império, realimentando-se conjunturalmente o antilusitanismo. ${ }^{11} \mathrm{Na}$ Vila de Viseu, próximo à fronteira com o Maranhão, houve denúncia de que líderes locais da facção liberal haviam dito que no 7 de setembro de 1874 os brasileiros haveriam de "darem muita pancada em os Portuguezes; e pollos fora da terra", não se dando o fato porque o subdelegado de polícia de Viseu tivera apoio de uma força militar enviada pelo comandante da Colônia Militar do Gurupi. ${ }^{12}$

Vicente Salles ajuda a entender a conjuntura que, em 1874, favoreceu 0 antilusitanismo dos liberais de Viseu. Na época, o jornal semanal reformista, nativista e pró-republicano A Tribuna, editado em Belém entre 1870 e 1876, que reuniu simpatizantes da Internacional Socialista e liberais, havia deflagrado campanha contra os portugueses que dominavam o comércio a retalho no Pará. Esta polêmica campanha talvez tenha contagiado os liberais de Viseu. Embora, o Partido Liberal no Pará, em manifesto de 26 de novembro de 1874, tenha repudiado o ódio aos portugueses por parte d'A Tribuna, da mesma forma que a dissidência conservadora fizera em seu manifesto de 30 de novembro de $1874{ }_{1}{ }^{13}$ sendo manifestações em resposta ao episódio ocorrido em Viseu, senão em outras partes da província. Anos mais tarde, na capital paraense, foi o padeiro português Antonio Alves Garcia vítima da exaltação dos ânimos patrióticos de alguns brasileiros quando das festividades cívicas, levando algumas pancadas. Em 1883, na primeira vez, na porta de sua padaria lá estava "quando festejava-se o dia 15 de agosto" sendo "provocado e esbordoado por alguns desordeiros, que até carregaram-Ihe com a cadeira em que estava assentado"; em 1884, na segunda vez, na noite de 2 de julho, "na occazião em que desfilava pela rua de S. Vicente a passeata promovida pelos bahianos", foi o padeiro português espancado "por alguns indivíduos" movidos pelo "furor patriótico". Foi então que o padeiro Garcia se queixou à imprensa, prevendo novas pancadas em 15 de agosto e talvez mais ainda no 7 de setembro de 1884, uma vez que apanhando nas "adesões" provinciais à independência brasileira, porque não haveria de apanhar no próprio dia dela? ${ }^{14}$

Penso, no entanto, que as comemorações das efemérides provinciais das "adesões" à independência nacional ganharam maior importância e apelo social mais precisamente nas duas últimas décadas da monarquia. Sendo possivel compreende-las num contexto cada vez mais marcado pelas ideias de federação, inclusive de uma monarquia federativa. 0 que não quer dizer que cada província, comemorando suas "adesões" e todas juntas 07 de setembro, não comemorassem as datas das "adesões" de outras províncias brasileiras. No Pará se comemorava o 2 de julho ou o 28 de julho, data da "adesão" maranhense, para maior azar do citado padeiro português Garcia, ainda que sem a mesma pompa e importância que o 15 de agosto. ${ }^{15}$ As comemorações das "adesões" de outras províncias eram objeto e razão de ser de sociedades patrióticas fundadas em Belém do Pará pelos membros das colônias dessas províncias. A Sociedade Beneficente 28 de Julho, fundada em 1869 por membros da colônia maranhense e atuante até ao menos a década de 1880, tinha nas comemorações do 28 de julho sua principal atividade ${ }^{16}$ mas participava das festas de outras "adesões" promovidas por sociedades congêneres. Assim, a Sociedade 28 de Julho participou das festividades do 2 de julho de 1884 feitas pelos baianos e 
Cf. 2 de Julho. Diário de Notícias, 6 de julho de 1884 , p. 3. Ver, ainda: 2 de Julho. Diário de Notícias, 1 de julho de 1884, p.2; e Festival Bahiano. Diário de Noticias, 3 de julho de 1884, p. 2. As festas na própria Bahia também eram notícias, como se pode ver em: 2 de Julho na Bahia. Diário de Notícias, 19 de julho de 1884, p.2. Sobre a criação da Associação de Beneficência 2 de Julho, ver: Festival Bahiano. Diário de Notícias, 3 de julho de 1884, p.2; e Associação de Beneficência 2 de Julho. Diário de Notícias, 6 de julho de 1884, p.2.

18

Sobre essas associações, ver, por exemplo, Club Baptista Campos. Diário de Notícias, 8 de julho de 1884, p.3; Club Baptista Campos. Diário de Notícias, 10 de julho de 1884, p.2; 15 de Agosto. Diário de Notícias, 16 de julho de 1884, p.2. Sobre Batista Campos, ver SILVA, João Nei Eduardo da. Batista Campos: uma discussão biográfica na historiografia paraense. In: BEZERRA NETO, José Maia; GUZMÁN, Décio Alencar (Orgs.). Terra Matura: Historiografia e História Social na Amazônia. Belém: Editora Paka-Tatu, 2002. p.139-149. Sobre Tenreiro Aranha, ver BEZERRA NETO, José Maia. Por todos os meios legítimos e legais... Op. Cit. Sobre Dom Romualdo de Souza Coelho, ver: REIS, Arthur Cezar Ferreira. Dom Romualdo de Souza Coelho. Escorço biographico. Belém: sem editora, 1941; e MUNIZ, João de Palma. Dom Romualdo de Souza Coelho. Revista do Instituto Histórico e Geographico do Pará Belém, vol.06, p.217-223, 1931. Sobre o processo de independência no Pará, ver: COELHO, Geraldo Mártires. Anarquistas, Demagogos e Dissidentes: a imprensa liberal no Pará de 1822. Belém: CEJUP, 1993; SOUZA JÚNIOR, José Alves de. Constituição ou Revolução: os projetos políticos para a emancipação do Grão- Pará e a atuação de Filippe Patroni (1820-1823). 1996. 279f. Dissertação (Mestrado em História Social do Trabalho). Programa de Pós Graduação em História, Universidade Estadual de Campinas, Campinas-SP, 1996; e MACHADO André Roberto de Arruda. A Quebra da Mola Real das Sociedades: a crise política do Antigo Regime Português na província do Grão-Pará (1821-1825). São Paulo: Hucitec/Fapesp, 2010.

19

Cf. Portaria de 20 de junho de 1882. Coleção das Leis da Província do Grão-Pará, tomo 44, 1881-1882, parte 2 .

20

Sobre a Sociedade 15 de Agosto ver Fundo: Sociedade Quinze de Agosto, Série: Atos de Assentamento, Datas-Limite: 1879-1889, Arquivo "Palma Muniz" do Instituto Histórico e Geográfico do Pará. Ver, também, Sociedade 15 de Agosto. Diário de Notícias, 18 de julho de 1884, p.3.

21

Cf. Ofício de diversos artistas nacionais ao Presidente da Província do Pará, em 9 de agosto de 1884, Fundo: SPP, Série: Ofícios, Ano:18801882, Caixa: 382 (Ofícios das sociedades e associações), APEP.

22

Cf. Para 15 de Agosto. Diário de Notícias, 26 de julho de 1884, p.3. sergipanos residentes em Belém, principalmente os primeiros. Quando destes festejos patrióticos fora criada a sociedade de socorros mútuos 2 de Julho. ${ }^{17}$

Além dessas associações de inspiração mutualista e patriótica, outras se fundaram em Belém com igual teor, batizadas com nomes dos que fizeram história e deixaram memória como partidários da independência paraense e de sua "adesão" ao Império. Assim, havia o Club Baptista Campos, referência ao Cônego João Baptista Gonçalves Campos (1782-1834); o Club Tenreiro Aranha, lembrando João Baptista de Figueiredo Tenreiro Aranha (1790-1861), que tinha José Verissimo como seu orador; o Club D. Romualdo, em homenagem ao $8^{\circ}$ bispo do Pará envolvido com o processo de "adesão" paraense, Romualdo de Souza Coelho (1762-1841). ${ }^{18}$ Conheço um pouco melhor o Club Baptista Campos, com estatutos aprovados pelo governo provincial em 20 de junho de 1882. No seu capítulo 1, "Do Club e seus fins", definiu-se que seu fim era "promover, por meio de manifestações patrióticas na praça 'Baptista Campos' os festejos do anniversário do glorioso dia 15 de agosto de 1823, data da nossa emancipação política".19

Houve também a Sociedade 15 de Agosto, fundada em 1879 e que parece ter existido até $1889,{ }^{20}$ cujo nome indica seu caráter patriótico, visando à comemoração da "adesão" paraense à independência, embora não fossem tais festas cívicas unicamente comemoradas por ela. Neste sentido, vários artistas nacionais em 9 de agosto de 1880 oficiaram ao presidente provincial a decisão de "solemnizar o dia 15 de Agosto, anniversario de nossa adhesão à causa da independência política e emancipação do Império", desejosos em "dar a mais expansiva prova de regosijo por tão faustoso quanto enthusiastico acontecimento, percorrendo em passeata pacifica, ordeira e patriótica as ruas desta Capital". Para isto, pediam a cessão de "uma das bandas de musica marciais disponiveis para preceder o préstito da referida passeata" durante a noite de 14 de agosto. Mas, a resposta governamental, mesmo imediata, foi desfavorável, porque todos os músicos já estavam cedidos para a Comissão Central encarregada dos festejos cívicos que aconteceriam nos dias $14 \mathrm{e}$ 15 de agosto daquele ano. ${ }^{21}$ Enfim, festejar a data cívica do 15 de agosto parecia tão na moda que, em julho de 1884, a Loja Marselheza anunciou o "mais completo sortimento de balões para illuminação" visando a proximidade do 15 de agosto. ${ }^{22}$

015 de agosto, no entanto, não foi a única data cívica festejada no Pará ao longo de boa parte do século XIX. Houve outra, desde a década de 1830, menos importante e menos recorrente, mas também relacionada ao processo de construção do Estado Nacional brasileiro na Amazônia. Trata-se do 13 de maio, data que remete ao dia 13 de maio de 1836 quando os cabanos e seu último presidente, Eduardo Angelim, abandonaram a capital paraense, que ficou em poder das tropas da legalidade. Assim, a data representa o fim da Cabanagem, movimento popular ocorrido na província entre os anos de 1835 e 1840, e, sendo marco do retorno da ordem legal, foi alçada à condição de efeméride. Daí porque o 13 de maio em 1864 foi a data escolhida pelo presidente provincial, João Maria de Morais, para inauguração do serviço de iluminação pública a gás hidrogênio carbonado em Belém, por ser "este o [dia] da commemoração da restauração desta Capital depois das luctas de 1835"; sendo acesos 752 lampiões, além de algumas decorações iluminadas a gás na entrada do palácio presidencial e em diferentes pontos da cidade tornando mais pomposa a inauguração 
Cf. Ofícios n. 43, 51, 52 e 56 da Repartição das Obras Públicas da Província do Pará em 19 de abril e 6, 12 e 19 de maio de 1864, ao Presidente da Província do Pará, João Maria de Morais, Fundo: SPP, Série: Ofícios, Ano: 1851-1864. Caixa: 158 (Ofícios da Iluminação Pública). Citação do ofício n.52.

24

Cf., por exemplo, LYRA, Maria Loudes Viana. A utopia do poderoso império: Portugal e Brasil: bastidores da política, 1798-1822. Rio de Janeiro Sette Letras, 1994; MALERBA, Jurandir. A Corte no exílio. Civilização e poder no Brasil às vésperas da independência (1808-1821). São Paulo: Companhia das Letras, 2000; DAIBERT JUNIOR, Robert. Isabel, a "Redentora" dos Escravos. Uma história da Princesa entre olhares negros e brancos (1846-1988). São Paulo: Edusc/Fapesp 2004; e SCHWARCZ, Lilia Moritz. Op. Cit

25

Apud BAKOS, Margaret Marchiori. RS: Escravismo \& Abolição. Porto Alegre: Mercado Aberto, 1982. p.150.

26

Cf. BEIGUELMAN, Paula. Pequenos Estudos de Ciência Política. São Paulo: Pioneira, 1973. p.145.

27

Apud BAKOS, Margaret Marchiori. Op. Cit., p.63.

28

Cf. NABUCO, Joaquim. A escravidão e o Brasil perante o mundo. In: Campanhas de Imprensa (1884-1887). São Paulo: Instituto Progresso Editorial S. A., 1949. p.70-75. Citação da p.73.

29

Cf. Idem. Ainda o meeting abolicionista de Londres. In:_. Campanhas de Imprensa (1884-1887)...Op. Cit., p.76-81. Citação da p.80. desse serviço. ${ }^{23} \mathrm{~A}$ efeméride deste 13 de maio, inclusive, teria desdobramentos em seu entrelaçamento com o abolicionismo e a abolição no Pará, como ver-se-á depois.

Enfim, os festejos das datas cívicas que compunham o calendário cívico do império têm sua importância melhor compreendida a partir da historiografia mais recente sobre a monarquia no Brasil, que é reveladora da aceitação da monarquia e de seus símbolos por parte da sociedade. A monarquia, portanto, estava longe de ser tão-somente um desvio de rota ou acidente de percurso no devir republicano brasileiro. ${ }^{24}$

Nos limites deste artigo, a partir da contextualização da importância das datas cívicas no Império, bem como para além da marcação dessas celebrações de patriotismo e civismo com alforrias de cativos, tenho por objetivo entender como emancipadores e abolicionistas buscaram ligar suas lutas antiescravistas com a memória e a história da emancipação política brasileira, compartilhando-a e reinventando-a, ou até mesmo criando efemérides, festas e tradições de natureza cívicas e patrióticas a serviço das causas emancipadora ou abolicionista.

\section{"A segunda independência"}

Sendo o "abolicionismo" ação política visando emancipar o Brasil da escravidão, embora "movimento" de forte apelo social, os emancipadores e abolicionistas construíram a imagem de sua "nobre e filantrópica causa" como herdeira das lutas dos que estiveram à frente do processo de emancipação política do Brasil. Assim, conferiam legitimidade ao "movimento abolicionista", já que lutar pela libertação dos escravos seria completar a obra inacabada dos fundadores da pátria brasileira, emancipando o solo brasileiro da última herança do domínio colonial português. Em Porto Alegre, capital gaúcha, quando das comemorações públicas da Lei Áurea em 14 de maio de 1888, contou o jornal liberal $A$ Reforma que o secretário do Centro Abolicionista "observou, em poucas palavras, que a ideia da redenção dos cativos datava de José Bonifácio, o Patriarca da Nossa Independência". ${ }^{25}$ A associação da luta emancipadora ou abolicionista à história da independência brasileira era resposta à acusação de escravagistas como Martinho Campos, que desqualificava o abolicionismo como "movimento artificial que não nasce da nação" ${ }^{26}$ ou então à retórica antiabolicionista do líder liberal Silveira Martins, que dissera no Senado "que não tomava posição ao lado dos que trabalhavam em favor da libertação dos escravos, porque era mais amigo da sua pátria do que do negro". 27 Em artigos no Jornal do Comércio, em 1884, na Corte, Joaquim Nabuco defendeu o abolicionismo como movimento patriótico em resposta aos escravocratas, demonstrando serem eles os impatrióticos. Tratando das abolições nas províncias do Ceará e do Amazonas, ele as qualificou como a "Segunda Independência"; ${ }^{28}$ criticando o xenofobismo dos partidários da escravidão que refutavam a ideologia abolicionista como estrangeirismo, Nabuco, ao contrário, afirmara sobre a abolição:

Isto, sim, é patriotismo verdadeiro, preocupação da honra nacional, compreensão dos supremos interesses da nossa pátria, cuja vida, progresso, futuro, elasticidade natural e crescimento, acham-se paralisados pelos interesses de uma propriedade ilegítima e contra a natureza, como é a propriedade humana. ${ }^{29}$ 
Cf. Associação Philantrópica de Emancipação de Escravos. Diário do Gram-Pará, 18 de janeiro de 1872, p.1. Grifos meus.

33

Cf. CARVALHO, José Murilo de. D. Pedro II. Ser ou não ser. São Paulo: Companhia das Letras, 2007. p.130.

34

Cf. NABUCO, Joaquim. 0 Sr. Martinho Campos e os abolicionistas. In:_. Campanhas de Imprensa... Op. Cit., p.109-112. Trechos citados nas p.109 e p.110.
A escravidão seria, então, testemunho da incivilidade brasileira, causa de vergonha e desonra face às nações civilizadas; daí que a sua continuidade e, pior ainda, a sua defesa, seria considerada a "aberração do patriotismo".30 Mais ainda, a escravidão em grande parte se fundava na propriedade ilegítima de centenas de milhares de escravos, ilegitima e ilegal em razão do fim do tráfico legal em 7 de novembro de 1831. Além de tudo, era instituição contrária aos princípios das leis naturais. Isto é, atentando contra a natureza e as leis do país, a escravidão violava o sentimento nacional brasileiro. Enfim, Nabuco definia o "abolicionismo" como movimento patriótico porque traduzia a vontade nacional em abolir a escravidão; mais que isto, traduzia os "interesses da nossa pátria" refém de proprietários de escravos que, preservando a escravidão, impediam o "progresso, futuro, elasticidade natural e crescimento" do Brasil. A abolição seria, então, causa patriótica, sendo seus partidários realizadores do que Nabuco chamou de "Segunda Independência". Aliás, as últimas palavras do prefácio de "O Abolicionismo", escritos por Nabuco em 8 de abril de 1883, em Londres, são esclarecedoras. Com elas, Nabuco manifestou sua esperança de ter, com seu livro, contribuído para unir, "em uma só legião os abolicionistas brasileiros, para apressar, ainda que seja de uma hora, 0 dia em que vejamos a independência completada pela abolição, e o Brasil elevado à dignidade de país livre, como o foi em 1822 à de nação soberana, perante a América e o mundo".31

A constatação acima, no entanto, não surgiu da leitura dos textos do famoso abolicionista pernambucano, ainda que esse fosse um caminho possivel. Mas sua leitura demonstrou afinidade com o que percebi nos discursos de certos emancipadores e abolicionistas paraenses, sendo então um imaginário político presente nas mentes e corações de outros partidários da abolição. Até porque foi a partir da pesquisa com notícias publicadas nos jornais paraenses sobre as sociedades emancipadoras e abolicionistas que percebi a filiação construída pelos partidários da emancipação escrava entre suas lutas e aquelas ocorridas quando do advento da independência brasileira. Assim, alguns anos antes da publicação de 0 Abolicionismo, em Belém, Samuel Wallace Mac-Dowell, em $1^{\circ}$ de janeiro de 1872, na sessão solene de posse dos novos diretores da Associação Philantrópica de Emancipação dos Escravos, havia dito ser a escravidão um "cancro moral" que desgraçadamente infeccionava a civilização do Brasil. Mac-Dowell, que era advogado, político conservador emancipacionista e presidia a referida sociedade, considerava a escravidão "o pior de todos os legados que nos foram transmitidos pelos tempos idos"; e por isso não se encontrando "na atualidade um só adepto, nem mesmo quem desculpe sua permanência provisória, senão pela necessidade de evitar maiores calamidades, que suppoem-se poderem surgir de sua abolição immediata......"32 Lembro que José Bonifácio já havia definido a escravidão como "o cancro que roia as entranhas da sociedade brasileira", tese recorrente entre emancipacionistas e abolicionistas. ${ }^{33}$

Dessa forma, emancipadores e abolicionistas viam-se como herdeiros da obra inacabada da independência política do Brasil, não sendo a abolição causa de um grupo de petroleiros ou anarquistas insurgentes e inovadores, influenciados pelas ideias estrangeiras. 0 abolicionismo era, portanto, um movimento patriótico, catalisador da materialização da vontade nacional. ${ }^{34}$ Foi neste sentido que, face à acusação de Martinho Campos no Senado de que os abolicionistas e a imprensa simpática a sua 
Cf. Emancipação de Escravos. Diário de Notícias 17 de julho de 1869, p.1.

37

Cf. RODRIGUES, Jaime. Liberdade, Humanidade e Propriedade: os escravos e a Assembleia Constituinte de 1823. Revista do Instituto de Estudos Brasileiros, São Paulo, n.39, p.159-167, 1995. Citação da p.159.

38

Ibidem, p.161.

39

Sobre a associação entre independência e liberdade quando das lutas de independência e nas décadas seguintes de formação do Estado Nacional e definição de seus sentidos e significados, ver REIS, João José. 0 jogo duro do Dois de Julho: o "partido negro" na independência da Bahia. In: REIS, João José; SILVA, Eduardo. Negociação e conflito: a resistência negra no Brasil escravista. São Paulo: Companhia das Letras, 1989. p.79-98. No Pará, ver MORAES, Cleodir da Conceição. Os 'negros'de Muaná: escravos e libertos na Independência do Pará. 1997. Monografia (Graduação em História). Departamento de História, UFPA, Belém, 1997; SALLES, Vicente. O Negro no Pará sob o regime da escravidão. Brasilia: MEC; Belém: Secult/ Fundação Cultural Tancredo Neves, 1988; e PINHEIRO, Luis Balkar Sá Peixoto. De Mocambeiro a Cabano: notas sobre a presença negra na Amazônia na primeira metade do século XIX. Terra das Águas: Revista de Estudos Amazônicos, Brasilia, vol.1, n.1, p.148-172, 1999.

40

Ver a respeito: RODRIGUES, Jaime. 0 infame comércio: propostas e experiências no final do Tráfico de africanos para o Brasil (1800-1850). São Paulo: Unicamp, 2000. causa eram gente "petroleira", Joaquim Nabuco afirmara que "longe de ser um petroleiro, só quer para o problema [da escravidão] uma solução verdadeiramente nacional". Dizendo mais: "Petroleiro, porém, é o sr. Martinho Campos, mas petroleiro da escravidão!". ${ }^{35}$ Sendo então patriotas, os partidários da emancipação escrava construíam a imagem dos escravocratas como inimigos da ordem devolvendo-Ihes o epíteto de petroleiros, sendo eles os verdadeiros inimigos de sua pátria. Fazendo, assim, uma reapropriação da memória e da história da emancipação brasileira, os abolicionistas e emancipacionistas apontavam para a abolição como devir histórico da sociedade ou uma espécie de reconciliação do Brasilnação consigo mesmo.

Fica, no entanto, uma indagação: como os emancipadores e abolicionistas podiam ligar a sua causa à emancipação do Brasil, após anos de distanciamento, quando os próprios fundadores da pátria não lograram fazer a abolição, nem sequer definiram uma política pautada pelo gradualismo emancipacionista, apesar das propostas apresentadas na época? Talvez uma matéria publicada no jornal Diário do Gram-Pará, apoiando a ideia da fundação da Associação Philantropica de Emancipação de Escravos, em 17 de julho de 1869, ajude a entender esta questão. Comentou o articulista a certa altura que:

A sorte d'aquelles desgraçados que tem escripto na côr da epiderme a setença da condemnação, parecia tão em relação com elles, que tinha-se no paiz que era lei natural que o negro fosse escravo. Se alguém fallava em abolir a escravatura era tido em conta de anarchista, e ia-se logo buscar-se um facto - a associação de Voltaire, o creador da opinião pública, com uma casa de importação de negros para justificar a qualificação. [...]

Agora sente-se a necessidade de melhorar o destino d' aquella gente. 0 Código constitucional não pode conter na mesma página liberdade e escravidão. ${ }^{36}$

Isto é, a abolição do elemento servil não se fez de imediato, quando do processo de emancipação política do Brasil, sob a alegação de que seria a ruína da jovem nação, ainda cambiante. No recinto da Assembleia Constituinte brasileira de 1823, o tema da escravidão foi questão quase ausente nos debates parlamentares, já que as referências à instituição servil e à condição dos escravos e seu pretendido direito à liberdade "foram poucas e encontram-se diluídas nos anais da Assembleia, em meio às questões da organização administrativa e política que se encaminharam na Constituinte".37 Até porque, durante o conturbado processo de constituição do Estado Nacional, a associação entre independência e liberdade por parte dos escravos, que não seria errada "ao menos no plano semântico", ${ }^{38}$ ameaçava sobremaneira a ordem social instituida, ao questionar seriamente o direito de propriedade senhorial. Daí que, frente à rebeldia escrava, até mesmo discussão da abolição da escravatura seria uma temeridade para os cidadãos do Império recém-independente. ${ }^{39}$ Isto explica em parte, pelo menos, porque foi sobretudo no $2^{\circ}$ Reinado que a permanência da escravidão tornou-se a denominada "Questão Servil", da mesma forma que, e parte desta nova realidade, o comércio de escravos africanos tornou-se tráfico no sentido de atividade ilegal, ilícita e imoral. ${ }^{40}$

Somente com a estabilidade adquirida no $2^{\circ}$ Reinado se criaram as condições para o amadurecimento da solução do "Problema Servil", sendo a Lei do Ventre Livre o mais importante passo neste sentido, após a interdição do tráfico de escravos entre a África e o Brasil. Esta, em termos 
41

Sobre a Sociedade Ypiranga, cf. HURLEY, Henrique Jorge. Noções de História do Brasil e do Pará. Revista do Instituto Histórico e Geográfico do Pará, Belém, vol.XI, p.200, 1938.

42

Sobre a Sociedade Emancipadora 7 de Setembro, cf. TENREIRO ARANHA, Bento Figueiredo de. A Terra, as cousas e o homem da Amazônia. Memórias históricas, geographicas, ethnographicas, mineralógicas, botânicas e zoológicas das minhas viagens atravez da Amazônia. Revista do Instituto Histórico e Geográfico do Pará, n.Il, p.157-168, 1918. Citação na p.167.

43

Cf. Club Abolicionista Patroni. Diário de Notícias, 19 de agosto de 1881, p.1. Ver, também, Club Abolicionista Patroni. Diário do Gram-Pará, 19 de agosto de 1881, p.1.

44

Cf. Club Patroni. Diário de Notícias, 19 de agosto de 1881 , p.2.

45

Ver a respeito: FLORES, Jacques. Panela de Barro. Crônicas, ensaios, fantasias. Belém: Secult, 1990; e SALLES, Vicente. 0 Negro no Pará... Op. Cit.

46

Cf. Sociedade Dramática. Diário de Notícias, 21 de agosto de 1881, p.2. Ver, também, Movimento abolicionista. Diário do Gram-Pará, 21 de agosto de 1881 , p.1. gerais, era a linha de raciocínio de muitos emancipadores e abolicionistas, que estabeleciam um elo entre a emancipação política e a emancipação dos escravos. Desta maneira, recompunha-se a identidade semântica entre independência e liberdade que antes os escravos haviam ousadamente tentado construir, mas que não se realizou por imposição dos senhores. $\mathrm{Na}$ segunda metade do século XIX, emancipadores e abolicionistas realizavam a associação semântica entre independência e liberdade, todavia dissociando-a da rebeldia escrava ameaçadora das hierarquias sociais que deviam ser preservadas mesmo após o fim da escravidão, já que seus pressupostos eram outros; isto é, a busca da legitimidade política da emancipação escrava ou abolição a partir da história e memória da independência.

Associando a causa emancipadora à consecução plena da independência, os abolicionistas e emancipadores se reapropriavam dos elementos constitutivos da memória e da história da emancipação política brasileira quando elegiam lugares, efemérides e sujeitos deste passado, identificando-os com as lutas pela abolição. Em 1858, quando o movimento pela emancipação escrava no Pará dava seus primeiros passos, surgiu a Sociedade Ypiranga, criada por Antônio David Vasconcelos Canabarro, João Baptista de Figueiredo Tenreiro Aranha e Manuel Antônio Rodrigues. Esta sociedade consagrada aos festejos das efemérides pátrias, queria solenizar as datas de 15 de Agosto, dia da "adesão" paraense à independência, e de 7 de Setembro, com a alforria de escravos. ${ }^{41}$ Ainda em dezembro de 1858, Tenreiro Aranha e Canabarro haviam fundado a Sociedade Emancipadora 7 de Setembro. ${ }^{42}$ As denominações dessas sociedades já mostram o que foi dito há pouco.

Décadas depois, em 1881, quando o abolicionismo encontrara seu tempo e lugar na sociedade brasileira, surgiram no Pará o Club Abolicionista Patroni e a Sociedade Dramática Abolicionista 15 de Agosto. 0 primeiro surgiu com o "fim especial" de alcançar com os "donativos dos associados a libertação de escravos, distribuindo as cartas de manumissão no dia 15 de agosto".43 Tais abolicionistas associavam-se à legenda de Felipe Patroni, realimentando a memória dele como um partidário da emancipação política brasileira, como comenta o Diário de Noticias ao dizer que os fundadores do Club "tiveram a feliz lembrança de dar o nome do primeiro paraense que ousou pela imprensa propagar a emancipação política de seus conterrâneos". ${ }^{4}$ Intuo ainda que a escolha do nome de Patroni devase à imagem que the foi imputada por seus adversários políticos como defensor da libertação dos escravos, quando do início da década de 1820. Embora Patroni tenha perdido a oportunidade de dar testemunho de seu imputado anti-escravismo quando decidiu migrar para Portugal em meados do século XIX, fazendo a venda de sua escrava ao invés de libertá-la, a imagem que dele se construiu foi a de um abolicionista, inclusive sendo uma memória histórica construída pelos abolicionistas da agremiação que levou seu nome..$^{45}$ No entanto, o Club Patroni ainda estreitou seus vínculos de identidade com o imaginário cívico da emancipação pátria quando elegeu preferencialmente o 15 de agosto como a data para a entrega solene e pública das alforrias aos escravos. A Sociedade Dramática Abolicionista 15 de Agosto, por sua vez, fundada por "amadores luzo-brasileiros" em 15 de agosto de 1881, visando "remir do captiveiro os infelizes escravos, promovendo para isso representações theatraes e basares, e angariando donativos" ${ }^{46}$ trazia em seu nome a efeméride maior da história paraense daqueles idos. 
47

Cf. BAKOS, Margaret Marchiori. RS... Op. Cit., p.114-116.

48

Sobre o Ceará, ver SILVA, Pedro Alberto de Oliveira. História da Escravidão no Ceará. Das origens à extinção. Fortaleza: Instituto do Ceará, 2002, p.222 e p.226.

49

Cf. DUQUE-ESTRADA, Osório. A Abolição (Esboço Histórico), 1831-1888. Rio de janeiro: Livraria Editora Leite, Ribeiro \& Maurillo, 1918. p.215.

50

Cf. REIS, Arthur Cezar Ferreira. Súmula de História do Amazonas (Roteiro para professores). Manaus: Edições Governo do Estado do Amazonas, 1965. p.62.

51

Célia Azevedo chama atenção para o fato de que o abolicionismo brasileiro adotou uma linguagem secular, "na qual a figura central é o progresso e suas correspondentes leis humanas", cf. AZEVEDO, Célia Maria Marinho de. Abolicionismo. Estados Unidos e Brasil, uma história comparada (século XIX). São Paulo: Annablume, 2003. p.44. Ver ainda a p.166. David Brion Davis também já tratara da questão, cf. DAVIS, David Brion. O Problema da Escravidão na Cultura Ocidental. Rio de Janeiro: Civilização Brasileira, 2001.

52

Cf. AZEVEDO, Célia Maria Marinho de. Abolicionismo... Op. Cit., p.96.

53

Cf. NABUCO, Joaquim. A Escravidão. Compilação, organização e apresentação de Leonardo Dantas Silva. Rio de Janeiro: Nova Fronteira, 1999. p.104 e p. 105.
No restante do Brasil, há outros exemplos. A 7 de setembro de 1880, na Corte, fundou-se a Sociedade Brasileira contra a Escravidão. No Rio Grande do Sul, o 7 de setembro de 1884 foi a data escolhida para encerramento do movimento emancipador em Porto Alegre, com a realização de uma grande quermesse visando a emancipação de seus escravos. ${ }^{47}$ No Ceará, a Sociedade Emancipadora do Atheneo Cearense alforriou a escrava Rosa em 7 de setembro de 1875. Nesta província, aliás, o 25 de Março, efeméride relativa à constituição de 1824 , foi data várias vezes escolhida para entrega de alforrias, sendo igualmente data eleita para fundação de associações abolicionistas, além de ser o dia escolhido para consagração da abolição no Ceará. ${ }^{48} 025$ de março rememorava o nascimento da constituição brasileira que consagrou a liberdade política e a liberdade individual dos cidadãos do Império, sendo por isso escolhido pelos abolicionistas. Efeméride, inclusive, que ganhou importância por conta das práticas abolicionistas cearenses, sendo reapropriada por outros emancipadores e abolicionistas, como os que fundaram em Campos, no Rio de Janeiro, um jornal abolicionista de nome Vinte e Cinco de Março, empastelado em 26 de outubro de 1887. ${ }^{49}$ Já no Amazonas, houve a fundação da Libertadora Vinte e Cinco de Março. ${ }^{50}$

Cabia, então, aos emancipadores e abolicionistas, em suas diversas sociedades e escudados na imprensa, fazer da causa da liberdade não só uma realização humanitária e civilizadora, mas igualmente patriótica em seu desmonte da escravatura, instituição que, herança do período colonial, já não mais caberia no seio da pátria brasileira em sua busca rumo ao progresso moral e material. ${ }^{51}$

Estas considerações permitem problematizar a tese de Célia Azevedo que, em estudo comparativo do abolicionismo brasileiro e norte-americano, considerou que os militantes brasileiros dissociaram abolicionismo e independência nacional. Para a autora, "enquanto os abolicionistas americanos podiam relacionar a luta pela liberdade à revolução, e a partir disso, denunciar a incongruência da escravidão inscrita na constituição, os abolicionistas brasileiros viam-se obrigados a procurar em outros lugares a memória histórica da busca da liberdade". 52

As considerações de Azevedo podem ser também relativizadas em outro sentido: para os abolicionistas brasileiros era também possivel estabelecer certo elo entre as lutas pela independência no Brasil e a abolição, havendo ao menos uma revolução para lembrar associando-a à luta pela liberdade, no caso a Revolução Pernambucana de 1817. Joaquim Nabuco já havia estabelecido esta filiação em sua obra inacabada e publicada postumamente, o seu manuscrito A Escravidão, cujas duas primeiras partes, $O$ crime e $A$ história do crime, foram escritas por volta de 1869, faltando a última, A reparação do crime. Nesta obra, disse Nabuco: "Foi no movimento de 1817, o mais glorioso do nosso passado, que a ideia da emancipação apareceu pela primeira vez clara e distinta". Nabuco citava a Declaração do Governo Provisório Revolucionário de 1817 que, tranquilizando as classes proprietárias pernambucanas, expressava o desejo de uma emancipação que extirpando o "cancro da escravidão" seria, no entanto, "lenta, regular e legal".53 Relacionando a emancipação escrava à Revolução Pernambucana, Nabuco lamentava então a derrota deste movimento revolucionário, e com ele a proposta de fim ao tráfico negreiro que 
Cf. MOTA, Carlos Guilherme. Nordeste 1817 estruturas e argumentos. São Paulo: Perspectiva/ EDUSP, 1972

56

Cf. NABUCO, Joaquim. A Escravidão... Op. Cit., p.107.

57

Cf. 0 Abolicionista. Recife: Fundação Joaquim Nabuco/Editora Massangana, 1988. Edição fac-simile de $1^{\circ}$ de novembro de 1880 a $1^{\circ}$ de dezembro de 1881.

58

Cf. Dous de Julho. Diário do Gram-Pará, 2 de julho de 1881, p.1. teria desaparecido no alvorecer de nossa independência, se nossa independência se tivesse inspirado no ideal, ou melhor, se nossa independência datasse de 6 de março de 1817. 0 despotismo, porém, tinha vida longa, e antes de sucumbir devia ele ainda matar a ideia emancipadora; foi assim que as armas portuguesas, (...), alcançaram dois fins: prolongaram por cinco anos a colônia, prolongaram talvez por um século a escravidão. ${ }^{54}$

Ao associar a Revolução Pernambucana de 1817 e a emancipação dos escravos, Nabuco fazia uma instrumentalização política do passado em favor do abolicionismo; assim, seus argumentos eram de ordem ideológica e não dizem necessariamente sobre o que de fato se deu no passado. Carlos Guilherme Mota, em estudo sobre a Revolução de 1817, permite problematizar essa relação, pois mostra os compromissos dos ditos revolucionários com o status quo escravista. ${ }^{55}$

De qualquer forma, ao instituir a relação entre o projeto de 1817 e a emancipação dos escravos, ao manifestar sua predileção pelos revolucionários de 1817, Nabuco não pretendia dissociar de todo a causa da libertação dos escravos do processo da independência brasileira ocorrido na década de 1820. Tratando do projeto emancipador do "venerando José Bonifácio", escreveu ele: "É por isso que colocamos a causa emancipadora já protegida pelos mártires de nossa independência sob a invocação do patriarca desta". ${ }^{56}$ Isto tudo, é verdade, escreveu quando jovem bacharelando de Direito no Recife, quando ainda era emancipador, não o maduro abolicionista de anos depois. É também verdade que a redação de $A$ Escravidão nunca foi concluída e a obra jamais publicada por iniciativa do autor. Tudo isso faz com que se dê pouca importância às formulações de Nabuco em A Escravidão. Mas ressalvo que, se de um lado, obras posteriores como $O$ Abolicionismo, refletem muito daquilo que o jovem Nabuco já havia escrito, por outro, ele e seus partidários à frente do jornal 0 Abolicionista, publicado na Corte entre 1880 e 1881 como órgão da Sociedade Brasileira Contra a Escravidão, defendiam justamente essa construção ideológica entre abolição e Revolução Pernambucana de $1817 .{ }^{57}$ Ao que parece, portanto, havia pelo menos uma revolução, ainda que derrotada, para lembrar.

Enfim, independente da Revolução Pernambucana de 1817 e sua associação à causa da liberdade dos escravos, cujo republicanismo os abolicionistas monarquistas pareciam ignorar em seu contorcionismo ideológico, no século XIX o imaginário em torno da emancipação política do Brasil foi campo fértil para a semeadura abolicionista e emancipacionista, sendo este 0 caso das efemérides das diversas "adesões" das províncias brasileiras ao Império do Brasil. Em 1881, por exemplo, o 2 de Julho, dia do "anniversario da independência bahiana", foi escolhido pela Associação Emancipadora de Emancipação dos Escravos para a realização de sua "modestíssima, porém eminentemente philantrópica festa emancipadora", uma vez que "A .. liberdade associa-se assim à idéa de liberdade; a idéa do patriotismo à de patriotismo; a idéa de emancipação à de emancipação!".58 Nesta mesma linha, também se comemorava há mais tempo em Belém o 28 de Julho, efeméride da "adesão" maranhense.

Vicente Salles já havia percebido que as sociedades emancipadoras e abolicionistas não perdiam a oportunidade de dar maior publicidade a seus atos em favor da causa da liberdade, e para isso elegia as efemérides como momentos privilegiados de ação. Assim, percebe-se o caráter propagandístico e pedagógico das alforrias dos escravos por parte dos emancipadores 
59

Cf. SALLES, Vicente. O Negro no Pará... Op. Cit., p.307.

60

Cf. SILVA, Pedro Alberto de Oliveira. Op. Cit., p.155-156.

61

Cf. DUQUE-ESTRADA, Osório. A Abolição... Op. Cit., p.196. Ainda sobre as comemorações da abolição no Ceará, em 25 de março de 1884, ver, deste autor, as páginas 115-119 do respectivo livro.

62

BEZERRA NETO, José Maia. Por todos os meios legitimos e legais... Op. Cit.
63

Ibidem; Idem. 0 Doce Treze de Maio. 0 abolicionismo e as visões da Cabanagem, Grão-Pará - Século XIX. In: NEVES, Fernando Arthur de Freitas; PINTO, Roseane Corrêa (Orgs.). As Várias Faces da História da Amazônia. Belém: Editora Paka-tatu, 2006. p.341-382. e abolicionistas, como registra Salles: "a entrega das cartas de liberdades se constituía ato público, solene, com vasta publicidade, e a data preferida era o 2 de dezembro, dia do aniversário natalício do imperador.".59 Embora minhas pesquisas não indiquem que o 2 de Dezembro fosse a data mais importante ou a mais recorrente entre os emancipadores e abolicionistas nos usos do calendário cívico do império, é compreensível que tenha sido importante, pois parcela significativa dos emancipadores e abolicionistas elegiam Pedro II como o primeiro partidário da causa da liberdade no país. Assim entendiam os filiados à Associação Emancipadora, mas não somente: no Ceará, a primeira "Comissão Especial de Manumissão de Escravos" de Fortaleza, em 1869, havia escolhido o "o grande dia 2 de dezembro" para entrega das alforrias. ${ }^{60}$

A liberdade associada à ideia de liberdade, patriotismo e independência Apesar da simbiose entre Estado e Igreja no Império, as referências de natureza religiosa nos discursos abolicionistas não ocorriam em tanta profusão, ao contrário do que ocorria em relação às efemérides pátrias. Emancipadores e abolicionistas não só se apropriavam das datas cívicas associando-as às suas lutas contra a escravidão, mas acabavam dandoIhes um novo significado e sentido comemorativo no contexto das lutas anti-escravistas; é o caso do 25 de Março que, desde 1884, passou a ser comemorado como dia da abolição cearense e assim festejado, tal como fez a Comissão Redemptora do Recife que "commemorou com grandes festas a data da emancipação do Ceará" em 1886. ${ }^{61}$ No Pará, igualmente celebrou-se o 25 de Março como marco da abolição cearense, havendo inclusive a fundação de sociedade abolicionista com tal denominação. ${ }^{62}$ Mas, ainda na província paraense, se tudo houvesse dado certo como planejado pela Liga Redemptora, fundada em abril de 1888 em Belém, outra data conheceria importante ressignificação: o 13 de maio. Falo, aqui, do 13 de maio de 1836, já comentado na primeira seção deste texto, data que remete à retomada de Belém do domínio cabano pelas tropas da legalidade regencial. Pois bem, foi justamente esta a data escolhida para solenização em 13 de maio de 1888 da redenção da capital do Pará do trabalho escravo, o que de fato não aconteceu, mas acabou ocorrendo em função da Lei Áurea, em outro 13 de maio. A escolha, no entanto, da efeméride do 13 de maio por parte significativa de emancipadores e abolicionistas paraenses organizados em torno da Liga Redemptora e escudados na imprensa periódica de Belém, que passaria a ter um novo significado como data da redenção da capital paraense, é reveladora dos limites e horizontes deste movimento emancipador ou abolicionista em seu apego à ordem social construída sob a égide do escravismo. Afinal, celebrando a derrota da Cabanagem, da qual haviam participado escravos na condição de rebeldes, esses emancipadores e abolicionistas paraenses demarcavam suas visões de liberdade dos escravos como sujeitos que, não devendo mais ser propriedade de outros, precisavam ainda ser tutelados, manietados e controlados, apesar, ou principalmente, em decorrência de sua nova condição de livres. Tais visões de fato vingaram, embora não tenha sido possivel o 13 de maio ser reinventado como efeméride da liberdade construída a partir da ordem e da preservação da autoridade dos antigos senhores. ${ }^{63}$

Para além dessas reinvenções, os emancipadores e abolicionistas foram hábeis em reinventar ou até mesmo em criar outras efemérides 
Cf. DUQUE-ESTRADA, Osório. A Abolição... Op. Cit., p.145.

65

Ver a respeito: SALLES, Vicente. Memorial da Cabanagem... Op. Cit., p.160-161.

66

Cf. DUQUE-ESTRADA, Osório. A Abolição... Op. Cit., p.145.

67

Sobre a referida lei, ver: MENDONÇA, Joseli Maria Nunes. Entre a mão e os anéis. A Lei dos Sexagenários e os caminhos da abolição no Brasil. Campinas: Editora da Unicamp/Cecult, 1999.

Sobre o conservantismo ver BEIGUELMAN, Paula. Formação Política do Brasil. São Paulo: Pioneira, 1976. p.154; que esclarece as reservas emancipacionistas para com os abolicionistas vistos como partidários de "um raciocínio incapaz de apreender a realidade empírica".

70

Cf. DUQUE-ESTRADA, Osório. A Abolição... Op. Cit., p.93.

71

Cf. BEIGUELMAN, Paula. Formação Política do Brasil... Op. Cit., p.138.

72

Cf. BAKOS, Margaret Marchiori. RS... Op. Cit., p.36. ou lugares da memória a partir da história mais recente de desmonte do escravismo brasileiro, história da qual em algum momento também foram sujeitos. Assim, outra data recorrente, desde a década de 1870, foi a de 28 de Setembro, alusiva à aprovação da lei emancipadora de 1871, quando a imprensa e as sociedades emancipadoras e abolicionistas realizavam os "festejos" comemorativos dos anos da Lei Paranhos ou Lei do Ventre-Livre. Neste dia, por exemplo, em 1884, foram libertados os escravos do Largo de São Francisco em São Paulo. ${ }^{64}$ Era, então, 028 de Setembro uma data consagrada à liberdade. Para além das festas da liberdade em seu dia, o apelo imagético do 28 de Setembro se revelou ainda na fundação da Sociedade Abolicionista 28 de Setembro, em meados da década de 1880, em Belém, organizada por segmentos das classes trabalhadoras e populares e com destacada atuação na campanha da abolição, existindo anos antes uma outra denominada Sociedade Beneficente 28 de Setembro, fundada em 1872. ${ }^{65}$ No Rio Grande do Sul, em D. Pedrito, em 6 de outubro de 1884, o Barão de Upacarahy fundou o Club Libertador Vinte e Oito de Setembro, com a entrega de 260 cartas de liberdade. ${ }^{66}$ Lembrando ainda que a chamada Lei dos Sexagenários foi também sancionada em 28 de setembro, não por acaso. ${ }^{67}$

Nesse contexto de construção de lugares da memória como espaços de suas campanhas libertadoras, os abolicionistas também rememoravam o 7 de Novembro de 1831, data da primeira lei brasileira anti-tráfico, instrumentalizando-a em seus embates contra os governos imperiais e seus opositores. Em 1869, Rui Barbosa, baseado na Lei de 7 de Novembro de 1831, já havia declarado a "illegalidade da escravidão". Muitos anos depois, em 1885, no Teatro Lucinda, na Corte, foi comemorada a efeméride de 7 de Novembro com discursos de Rui Barbosa, José do Patrocínio e Cyro de Azevedo. A Confederação Abolicionista, por sua vez, criou o Livro Sete de Novembro para registro dos nomes dos que alforriavam escravos, havendo ainda a fundação de um Club Abolicionista Sete de Novembro em dado momento. ${ }^{68}$ Estes são exemplos significativos da força imagética forjada pelos abolicionistas em sua instrumentalização política da memória e história nacionais; e neste caso, não eram acompanhados pelos emancipacionistas, que em seu gradualismo e conservantismo político preferiam um imaginário comemorativo de datas com apelos políticos e sociais bem menos explosivos. ${ }^{69}$

Os próprios emancipadores e abolicionistas, ao menos os mais conhecidos e festejados, sendo legendas das lutas contra a escravidão, tornavam-se ícones da memória, havendo a fundação de sociedades com seus nomes, tais como a Caixa Libertadora José do Patrocínio; Centro Abolicionista Ferreira de Menezes; Centro Abolicionista Joaquim Nabuco; Caixa Emancipadora Joaquim Nabuco e Caixa Emancipadora Vicente de Souza. ${ }^{70}$ Também Rio Branco era lembrado: suas exéquias, em novembro de 1880, "transformam-se em ensejo para manifestações abolicionistas, promovidas por André Rebouças, sendo a glória do estadista ressaltada como um lembrete para a necessidade de prosseguir-se sua tarefa".71 Esta, no entanto, era uma memória de emancipadores e abolicionistas monarquistas que, festejando o 28 de setembro ou o 2 de dezembro, festejavam o Visconde do Rio Branco e Pedro II como legendas do abolicionismo. Daí a fundação em Porto Alegre, na década de 1870, da Sociedade Visconde do Rio Branco. ${ }^{72}$ Também na capital gaúcha, a 7 de setembro de 1884 , as tendas da quermesse abolicionista receberam nomes significa- 
73

Cf. Ibidem, p.121.

74

A 16 de novembro de 1884, na 3ª Conferência no Teatro Santa Isabel, em Recife, Joaquim Nabuco dissera: "Não faz parte da nossa missão o elogiarmos hoje a lei de 28 de setembro; é a missão dos nossos adversários", demonstrando, aliás, a força do imaginário em torno da Lei Rio Branco. Cf. BEIGUELMAN, Paula. Formação Política do Brasil... Op. Cit., p.136. tivos: D. Pedro II, ou Visconde do Rio Branco; outras foram batizadas com os nomes de Eusébio de Queiróz, em razão da lei anti-tráfico de 1850; do Conselheiro Dantas, em virtude de seu projeto de libertação dos sexagenários; dos abolicionistas Luiz Gama e José do Patrocínio, e da folha abolicionista Jornal do Comércio. ${ }^{73}$ Vale lembrar, ainda, que tratamos aqui de uma memória que, não sendo unânime entre os abolicionistas em meados da década de $1880{ }^{74}$ não mais cabia a partir de 1889 , com a queda do regime imperial, sendo eclipsada por outra mais em consonância com a jovem república, que produzia críticas ao governo monárquico, inclusive em relação às suas leis emancipadoras.

Enfim, ainda que pesassem diferenças ideológicas, emancipadores e abolicionistas fizeram das datas forjadas no curso de seu movimento redentor lugares comemorativos de sua própria história, tornando-as efemérides da liberdade. Afinal, eles compreendiam o processo abolicionista como parte da constituição da nacionalidade brasileira. Uma nação brasileira que se livrando do fardo da escravidão, haveria de se querer igualmente redimida da presença escrava, mirando com os olhos os horizontes do modelo europeu de civilização branca ou branqueada. 